\title{
Antioxidant activity in different morphological fractions of some cereal grains
}

\author{
Slavica S. Šiler-Marinković, \\ Suzana I. Dimitrijević-Branković1, \\ Tijana M. Đorđević \\ ${ }^{1}$ Department of Biochemical \\ Engineering and Biotechnology, \\ Faculty of Technology and Metallurgy, \\ Karnegijeva 4, University of Belgrade, \\ 11000 Belgrade, Serbia \\ 2 Institute of Pesticide and Environment \\ Protection, Banatska 31 b, P.O.B. 163, \\ 11080 Belgrade, Serbia
}

\begin{abstract}
The purpose of this study was to examine the antioxidant properties of 70\% ethanolic extracts of cereal grains and their different morphological fractions. Wheat (Triticum durum L.), barley (Hordeum vulgare L.), rye (Secale cereale L.), and buckwheat (Fagopyrum esculentum) were used. The total phenolic content (TPC), determined by the Folin-Ciocalteu method and antioxidant activities (AOA) were assessed using 2,2-diphenyl-1-picrylhydrazyl (DPPH) scavenging capacity, ferric ion-reducing antioxidant power (FRAP) and thiobarbituric acid (TBA) methods. The following hierarchy of antioxidant activity was provided for $70 \%$ ethanolic extracts originated from whole grain: buckwheat $>$ barley $>$ wheat $>$ rye. In respect to hulls, the antioxidant hierarchy was the same. The outer layers of grains had higher amount of phenolic compounds and subsequently higher antioxidant activity. Buckwheat had the highest amount of total phenolics, with the highest $D P P H$ radical scavenging activity and capacity for $\mathrm{Fe}^{3+}$ reduction, but it had the lowest lipid peroxidation inhibition ability.
\end{abstract}

Key words: Antioxidant activity, total phenolic compounds, cereal grain extracts, morphological fractions

\section{INTRODUCTION}

Food antioxidants might play a significant role as physiological and dietary antioxidants, thereby augmenting the body's natural resistance to oxidative damage. It has been suggested that antioxidants may contribute to the health benefits of cereal-based foods by reducing the incidence of aging-related chronic diseases including heart diseases and some types of cancer.

Significant levels of antioxidants have been detected in cereals and cereal-based products [1,2]. Cereals also contain a wide range of chemical classes with antioxidant activity [3]. Cereal grains are rich in phenolic acids. Whole-grain cereals are a major source of polyphenols, especially phenolic acids such as ferulic, vanillic, caffeic, syringic, sinapic and $p$-coumaric acids. All of them have potentially antioxidant properties due to the presence of an aromatic phenolic ring that can stabilize and delocalize the unpaired electron within its aromatic ring. Other phytochemicals occurring in cereals are phytosterines, saponins, and phytoestrogens. In cereals, flavonoids are present in small quantities.

Cereal products have significant antioxidant potentials in vitro. Miller et al, [4], used the DPPH assay to show that the average antioxidant activity of cereals and cereal products is higher (between 1200 and 3500 mmol Trolox Equivalents (TE)/100 g of fresh product) than that of common fruit (mean: $1200 \mathrm{mmol} T E / 100$ g) and vegetables (mean: $400 \mathrm{mmol} T E / 100 \mathrm{~g}$ ), but lower than that of common berries (around $3880 \mathrm{mmol}$ $\mathrm{TE} / 100 \mathrm{~g})$.
Antioxidant properties of wheat based cereal products have been investigated by several research groups and reviewed by Baublis et al (2000). Research reports have been presented about the antioxidant potential of wheat bran and wheat flour [5]. The antioxidant capacity of the wheat bran fraction was $8500 \mathrm{mmol} \mathrm{TE} / 100 \mathrm{~g}$ and that of the germ fraction was $5000 \mathrm{mmol}$ TE/100 $\mathrm{g}$ [4]. Wheat extracts also have shown potential antioxidant properties as wheat phenolics appear to serve as powerful antioxidants through radical scavenging and/ or metal chelation [6]. Phenolics in wheat are acids derived from benzoic acid or cinnamic acid. It has also been reported that phenolic compounds are concentrated in the bran portion of cereal kernels and may contribute to the total antioxidant activities of wheat suggesting wheat bran a potent source of antioxidants.

Barley is an excellent source of natural antioxidants either for food preservation, or for disease prevention. There is growing interest in barley products because of their high content of antioxidants such as benzoic and cinnamic acid derivatives, proanthocyanidins, quinines, flavonols, chalcones, flavones, flavanones, and amino phenolic compounds [7]. Barley contains substantial amounts of phenolic antioxidants that effectively scavenge peroxyl, DPPH, and hydroxyl radicals, and effectively control oxidation of LDL cholesterol, thereby having a great potential in the development of nutraceuticals rich in antioxidants [8].

Rye is typically consumed in Scandinavian countries, especially as whole-grain rye bread. Ferulic acid is 
the predominant hydroxycinnamic acid, and the concentrations of its free and bound forms range from 900 to $1170 \mathrm{mg} / \mathrm{g}$ dry matter [9].

Buckwheat is an alternative crop belonging to the Polygonaceae family and is usually grouped with cereals because of similarity in cultivation and utilization though it is not cereal grain. Buckwheat grains have been well known as a plant source of rutin, quercetin, kaempferol-3-rutinoside, and a trace quantity of a flavonol triglycoside [10]. Buckwheat contains more rutin than most of the other plants, which exhibits antioxidative, antihemorrhagic and blood vessel protecting properties [11,12].

It has been shown that several factors, namely grain variety, environmental and growing conditions or milling and refining process of grains, can influence the presence and distribution of phenolic compounds and the final antioxidant power of cereal products $[1,3,13,14]$. Outer layers of grain usually contain a greater amount of polyphenolic compounds, as expected from their protective function in the plants. The bran fraction has been reported to have more antioxidant activity than other fractions. The total flavonoid concentrations of buckwheat seed and hull are 18.8 and 74 $\mathrm{mg} / 100 \mathrm{~g}$ flour, respectively [14]. Phenolic compounds in buckwheat have been reported to possess antioxidant activity and higher concentrations of these compounds are found in the outer layers of the grain containing bran $[10,12]$.

In this study, the effect of milling on the antioxidant activity and phenolic composition of some cereal grains was studied using in vitro models.

\section{MATERIALS AND METHODS}

\subsection{Materials}

The cereal samples used in this study included buckwheat (Fagopyrum esculentum) manufactured by Organic Biopharm, China, and wheat (Triticum durum), rye (Secale cereale) and barley (Hordeum vulgare) manufactured by KLAS d.o.o., Sarajevo. The compounds 1,1-diphenyl-2-picrylhydrazyl (DPPH), thiobarbituric acid (TBA) and gallic acid were purchased from SigmaAldrich Chemie GmbH (Taufkirchen, Germany), FolinCiocalteu reagent was purchased from Merck \& Co., Inc. (New York, USA), and all other chemicals and solvents were the highest commercial grades purchased from Lachema Ltd. (Brno, Czech Republic) and Fluka Chemie GmbH (Buchs, Switzerland), and used without additional purification.

\subsection{Preparation of cereal extracts}

Samples of whole grains, dehulled grains and hulls were grounded in mill Olovo (Bosnia and Hercegovina) and were obtained as flour. Samples were stored at -30 ${ }^{\circ} \mathrm{C}$ until extraction. Samples of each cereal fractions were prepared in triplicate.
The samples of cereal fractions (100 g each) were extracted with $70 \%(\mathrm{v} / \mathrm{v})$ ethanol $(700 \mathrm{ml})$ for $3 \mathrm{~h}$ on the magnetic paddle (Heidolph MR 3001, Sigma-Aldrich Chemie $\mathrm{GmbH}$, Taufkirchen, Germany), and then centrifuged at $3060 \mathrm{~g}$ (4500 rpm) for 10 min using the SIGMA 2-16 Versatile Centrifuge (MBI, Dorval, Canada). Extracts residues were re-extracted and the extracts were combined. Before drying samples were concentrated using the Büchi rotavapor R 210/215 (Büchi Labortechnik AG, Flawil, Switzerland) (temperature $50{ }^{\circ} \mathrm{C}$, pressure 50-150 mbar). Concentrated extracts were dried using the Büchi Mini Spray Dryer B-290 (Büchi Labortechnik AG, Flawil, Switzerland). Inlet temperature and pump were adjusted to $120-125^{\circ} \mathrm{C}$ and $15-20 \%$, respectively, leading outlet temperature of $60-63^{\circ} \mathrm{C}$. Dried samples were kept in hermetically sealed dishes in a freezer until further analysis.

\subsection{Determination of total phenolics content}

The content of total phenolics in extracts was determined by a modified Folin-Ciocalteu method [15]. Briefly, $100 \mu \mathrm{l}$ with $10-200 \mu \mathrm{g}$ of each dried extract were shaken for $1 \mathrm{~min}$ with $500 \mu \mathrm{l}$ of Folin-Ciocalteu reagent and $6 \mathrm{ml}$ of distilled water. After the mixture was shaken, $2 \mathrm{ml}$ of $15 \% \mathrm{Na}_{2} \mathrm{CO}_{3}$ were added and the mixture was shaken once again for $0.5 \mathrm{~min}$. Finally, the solution was brought up to $10 \mathrm{ml}$ by adding distilled water. After $2 \mathrm{~h}$, the absorbance was read on the UV/visible spectrophotometer (Ultrospec 3300 pro, Amersham Bioscience, Sweden) at $750 \mathrm{~nm}\left(25^{\circ} \mathrm{C}\right)$. The TPC was assessed by plotting the gallic acid calibration curve.

\subsection{Determination of DPPH radical scavenging activity}

Antioxidant activity of the ethanol extract was measured on the basis of scavenging activities of the stable 1,1-diphenyl-2-picrylhydrazyl (DPPH) radical [16]. In a lab dishes containing $50 \mu$ l of test samples of various concentrations were added: $3.95 \mathrm{ml}$ of methanol and $1 \mathrm{ml} 0.2 \mathrm{mM}$ of DPPH methanol solution. After $30 \mathrm{~min}$ of incubation in the dark at room temperature, the absorbance was measured against a blank (methanol) at $517 \mathrm{~nm}$ using the UV/visible spectrophotometer (Ultrospec 3300 pro, Amersham Bioscience, Sweden). Inhibition of DPPH radical was calculated as a percentage (\%) using the formula:

Percentage inhibition $(\%)=\left\{\left(A_{\text {control }}-A_{\text {sample }}\right) / A_{\text {control }}\right\} \times 100$ where, $A_{\text {control }}$ is the absorbance of the control reaction (containing all reagents except test compound), and $\mathrm{A}_{\text {sample }}$ is the absorbance of the test compound.

$I_{50}$ values (concentration of sample required to scavenge $50 \%$ of free radicals) were calculated from the regression equation, prepared from the concentration of the samples and percentage inhibition of free radical formation (percentage inhibition DPPH was assayed). Synthetic antioxidant L-ascorbic acid was used as a positive control and all tests were carried out in triplicates. 


\subsection{FRAP method}

In the FRAP method the yellow Fe ${ }^{3+}$-TPTZ complex is reduced to the blue Fe ${ }^{2+}$-TPTZ complex by electrondonating substances under acidic conditions. Any electron donating substance with a half reaction of lower redox potential than $\mathrm{Fe}^{3+} / \mathrm{Fe}^{2+}$-TPTZ $(2,4,6$, tri[2pyridyl]-s-triazine) will drive the reaction and the formation of the blue complex forward. To prepare the FRAP reagent, a mixture of $300 \mathrm{mmol} / \mathrm{l}$ acetate buffer $\mathrm{pH} 3.6$ (containing $6.4 \mathrm{ml} 2 \mathrm{~mol} / \mathrm{l}$ sodium acetate solution and $93.6 \mathrm{ml} 2 \mathrm{~mol} / \mathrm{l}$ acetic acid solution diluted in a volumetric flask, $10 \mathrm{mmol} / \mathrm{I} \mathrm{TPTZin} 40 \mathrm{mmol} / \mathrm{l} \mathrm{HCl}$ ) and $20 \mathrm{mmol} / \mathrm{l}$ ferric chloride (10:1:1, v:v:v) was made. 150 $\mu \mathrm{l}$ of ethanol plant extract were mixed with $4.5 \mathrm{ml}$ of FRAP reagent. The absorbance readings were started after $5 \mathrm{~min}$ and they were performed at $593 \mathrm{~nm}$ using the UV/visible spectrophotometer (Ultrospec 3300 pro, Amersham Bioscience, Sweden). The blank consisted of FRAP reagent. The final absorbance of each sample was compared with those obtained from the standard curve made from $\mathrm{FeSO}_{4} * 7 \mathrm{H}_{2} \mathrm{O}$. The results were expressed in $\mathrm{nmol} \mathrm{Fe}{ }^{2+} / \mathrm{mg}$ dried extracts [17].

\subsection{Thiobarbituric acid test (TBA)}

Thiobarbituric acid tests were performed to determine the TBA reactive substance (TBARS) from lipid peroxidation [18]. Lipid peroxidation was measured in the liposome rimifon Lipotech 10 (0.3 g lecithin $/ \mathrm{ml})$. The mixture contained $20 \mu \mathrm{l} \mathrm{FeSO} 4(0.075 \mathrm{~mol} / \mathrm{l}), 50 \mu \mathrm{li}$ posomes, $10 \mu \mathrm{l}$ of test samples of various concentrations (1-10\% w/v), $20 \mu \mathrm{L}$-ascorbic acid (0.1 M) and $3.9 \mathrm{ml}$ phosphate buffer $\mathrm{pH} 7.4$ (containing $5 \mathrm{ml}$ of 0.2 $\mathrm{mol} / \mathrm{l}$ monopotassium phosphate solution and $3.91 \mathrm{ml}$ of $0.2 \mathrm{~mol} / \mathrm{l}$ sodium hydroxide solution diluted in a volumetric flask $(20 \mathrm{ml})$ ).

The mixture maintained at $37^{\circ} \mathrm{C}$ for $1 \mathrm{~h}$ in thermostat and then mixed with $0.2 \mathrm{ml}$ ethylenediaminetetraacetic acid (EDTA) $(0.1 \mathrm{~mol} / \mathrm{l})$ and $1.5 \mathrm{ml}$ TBA reagent (3 $\mathrm{g}$ thiobarbituric acid, $120 \mathrm{~g}$ trichloroacetic acid and $10.4 \mathrm{ml}$ perchloric acid in $800 \mathrm{ml}$ demineralised water). After heating at $100^{\circ} \mathrm{C}$ for $15 \mathrm{~min}$, and centrifugation at $1107 \mathrm{~g}$ (3000 rpm) for $10 \mathrm{~min}$ using the SIGMA 2-16 Versatile Centrifuge (MBI, Dorval, Canada), the absorbance of the supernatant was measured at $532 \mathrm{~nm}$ using the UV/visible spectrophotometer (Ultrospec 3300 pro, Amersham Bioscience, Sweden). Inhibition of lipid peroxidation was calculated as percentage (\%) by the formula:

Percentage of inhibition $(\%)=\left\{\left(\mathrm{A}_{\text {control }}-\mathrm{A}_{\text {sample }}\right) / \mathrm{A}_{\text {control }}\right\} \times 100$ where, $A_{\text {control }}$ is the absorbance of the control reaction (containing all reagents and distilled water against test compound), and $A_{\text {sample }}$ is the absorbance of the test compound).

\section{RESULTS AND DISCUSSION}

\subsection{Total phenolics and antioxidant activities of whole grains}

The antioxidant activities and total phenolics of extracts of whole grains are shown in Table 1. All plants showed a significant amount of total phenolics and effective antioxidant activities. Buckwheat had the highest amount of total phenolics, with the highest DPPH radical scavenging activity and capacity for $\mathrm{Fe}^{3+}$ reduction, but it had the lowest lipid peroxidation inhibition ability. These data suggest that it might be more critical, in delaying lipid peroxidation, to suppress the initiation of radical chain reaction than to terminate it by quenching or removing the radicals generated during propagation of the radical chain reaction [19]. Other plants had similar TPC or AOA.

\subsubsection{Total phenolic content}

It has been shown that several factors, namely grain variety, environmental and growing conditions or milling and refining process of grains, can influence the presence and distribution of phenolic compounds and the final antioxidant power of cereal products $[3,13,14]$.

As shown in Table 1, total phenolic compound contents in the examined whole seed extracts were the highest in buckwheat, $50.7 \mathrm{mg} \mathrm{GAE} / \mathrm{g}$ dry extract. Lower total phenolic compound contents were present in wheat and barley (16.2 and $16.4 \mathrm{mg} \mathrm{GAE} / \mathrm{g}$ dry extract, respectively) and the lowest in rye $13.2 \mathrm{mg} \mathrm{GAE} / \mathrm{g}$ dry extract.

An asymmetric distribution of antioxidative components through the cereal grains was evident. The concentration of phenolic constituents was greater in the outer layers of the grain. The data reported had shown that phenolic acids are predominantly found in the outer bran layer of a wheat grain $[6,18]$.

As shown in a Table 1, the greatest source of phenolics is buckwheat hull (62.6 mg GAE/g dry extract). Other cereal brans have similar contents of phenolics (16.1-19.4 mg GAE/g dry extract). Content of total phenolics in examined cereal fractions of wheat, barley and rye were not very different. These resultes can be explained by the fact that the majority of phenolics in cereal grains are insoluble and bound by ester and ether linkages with polysaccharides, such as arabinoxylan and lignin, in the cell wall.

Covalently bound phenolic acids are concentrated in the cell walls of the various grain tissues especially the aleurone and the pericarp-seed coat where they are esterified to the arabinose side groups of arabinoxylans [19]. On the other hand, free and other soluble phenolics are mainly found in the aleurone layer and starchy endosperm of barley. The phenolic acids are mainly located in the outer layers of grain in free forms, which can be easily extracted using ethanol or methanol solutions. In contrast, the flavonoids existed in the buckwheat grain in the bound forms, which were 
bound to cell wall materials and needed further treatments to extract. However, rutin, one of main flavonoid in buckwheat grain, existed mostly in the free phenolic extracts using ethanol solution. The results of this study show that the phenolic compounds in buckwheat existed primarily in free form contrary to other cereals investigated.

The solubility of individual phenolics varies and the results may not be representative of the true phenolic content of grain fractions. The data reported by Zhou and $\mathrm{Yu}$ [13] had shown that the contents of TP in wheat and barley grain were affected by the extraction solvents in the following descending order: acetone $>$ ethanol > methanol, which can be used to explain lower amounts of phenols present in this plants (Table 1).

Besides, although the Folin-Ciocalteu method is widely used to determine total phenolic contents in botanical and biological samples, it has its own limitations. Other reducing agents, such as L-ascorbic acid and sulphur dioxide, may also react with the FolinCiocalteu reagent and contribute to total absorbance, which generally results in overestimated levels of total phenolic contents. In addition, individual phenolic compounds may have different reactivities toward the Folin-Ciocalteu reagent, which could result in potential errors in total phenolic content measurements [5].

\subsubsection{DPPH radical scavenging activity}

The DPPH radical has been widely used for assessment of radical scavenging activity because of the ease and convenience of the method. The scavenging effect of plant extracts using the highest sample concentra- tion $(200 \mu \mathrm{g} / \mathrm{ml})$, as shown in Table 2, was weak for the wheat extract, with only $31 \%$ DPPH radical inhibition. In other investigations, wheat extracts also demonstrated weak activity in scavenging the DPPH radical at this sample concentration [5]. Stronger scavenging effects on the DPPH radical were found for barley and rye (36.6\%and 45\%, respectively) (Table 2). The results of this work, showing significant DPPH radical inhibition ability for barley, are consistent with data reported by others, apart from differences in data interpretations. Madhujith and Shahidi (2006) demonstrated that barley contained substantial amounts of phenolic antioxidants that effectively scavenged free radicals, especially peroxyl, DPPH, and hydroxyl radicals [8]. The strongest scavenging effects on the DPPH radical were found for buckwheat extract (82.5\%) (Table 2).

The DPPH radical scavenging effect observed in this work is in agreement with literature data [20].

No correlation existed between TPC and DPPH radical scavenging activity in cereals (Table 1 ). The cereals with higher TPC values were not necessarily better in DPPH inhibition. Ferulic acid, the main phenolic acid in cereal grains, showed a weak antiradical effect in experiments with the DPPH radical, which may explain the discrepancies. Generally, there are several explanations of the ambiguous relationship between the antioxidant activity and total phenolics. The first, total phenolic content did not include all antioxidants, such as ascorbic acid, carotenoids and tocopherols. The synergism between antioxidants in the mixture made the antioxidant activity not only dependent on antioxidant concentration but on the structure and interactions

Table 1. Total phenolics and antioxidant activities of whole grains and their milling fractions

Tabela 1. Sadržaj ukupnih fenola i antioksidativna aktivnost nekih žitarica i njihovih morfolokih frakcija

\begin{tabular}{|c|c|c|c|c|c|}
\hline Sample name & Fraction & $\begin{array}{c}\text { TPC }^{A} \\
\text { (mg GAE/g dried } \\
\text { extract) }\end{array}$ & $\begin{array}{l}\mathrm{DPPH} \mathrm{H}^{\mathrm{B}}(\mathrm{IC} 50) \\
(\mu \mathrm{g} / \mathrm{ml})\end{array}$ & $\begin{array}{c}\text { FRAPC } \\
\text { (nm Fe }{ }^{2+} / \mathrm{mg} \\
\text { dried extract) }\end{array}$ & $\begin{array}{c}\text { TBARS } \\
\text { inhibition }^{\mathrm{D}} \\
(\%)\end{array}$ \\
\hline \multirow{3}{*}{$\begin{array}{l}\text { Buckwheat } \\
\text { (Fagopyrum } \\
\text { esculentum) }\end{array}$} & whole grain & 50.7 & 76.7 & 49.43 & 45.6 \\
\hline & bran & 62.6 & 69.2 & 57.42 & 58.9 \\
\hline & flour & 41.8 & 105.2 & 40.19 & 42.1 \\
\hline \multirow{3}{*}{$\begin{array}{l}\text { Barley (Hordeum } \\
\text { vulgare) }\end{array}$} & whole grain & 16.4 & 176.6 & 15.56 & 50.8 \\
\hline & bran & 19.4 & 155.8 & 18.5 & 56.8 \\
\hline & flour & 12.1 & 191.9 & 12.3 & 41.6 \\
\hline \multirow{3}{*}{$\begin{array}{l}\text { Wheat } \\
\text { (Triticum durum) }\end{array}$} & whole grain & 16.2 & 206 & 12.15 & 55.2 \\
\hline & bran & 18.9 & 195.2 & 15.35 & 57.2 \\
\hline & flour & 11.9 & 232 & 11.9 & 45.4 \\
\hline \multirow{3}{*}{$\begin{array}{l}\text { Rye } \\
\text { (Secale } \\
\text { cereale) }\end{array}$} & whole grain & 13.2 & 243 & 8.94 & 57.6 \\
\hline & bran & 16.1 & 169.6 & 12.13 & 59.8 \\
\hline & flour & 10.6 & 256 & 7.98 & 55.2 \\
\hline \multicolumn{6}{|c|}{$\begin{array}{l}\text { A. Total phenolics content (TPC) by Folin-C } \\
\text { B. DPPH radical scavenging activity. } \\
\text { C. Ferric reducing ability of plasma (FRAP). } \\
\text { D. Thiobarbituric acid method (TBA). }\end{array}$} \\
\hline
\end{tabular}


Slavica Šiler-Marinković et al: Antioxidant activity in different morphological fractions ...

Table 2. DPPH radical scavenging activity of whole grains and their milling fractions (\%)

Tabela 2. Antioksidativna aktivnost nekih žitarica i njihovih morfoloških frakcija određena DPPH metodom

\begin{tabular}{llccccc}
\hline \multirow{2}{*}{$\begin{array}{l}\text { Sample } \\
\text { name }\end{array}$} & \multirow{2}{*}{ Fractions } & \multicolumn{5}{c}{ Samhibition of DPPH radical, (\%) } \\
\cline { 3 - 7 } & & 10 & 20 & 50 & 100 & 200 \\
\cline { 3 - 7 } & whole grain & 11.6 & 21. & 34.8 & 63.3 & 82.5 \\
\cline { 3 - 7 } Buckwheat & bran & 13.8 & 25.2 & 39.7 & 72.2 & 96.4 \\
(Fagopyrum esculentum) & flour & 7.3 & 17.4 & 29.2 & 48.6 & 68.2 \\
\hline \multirow{2}{*}{ Barley } & whole grain & 4.5 & 6.5 & 17.9 & 29.0 & 36.6 \\
(Hordeum vulgare) & bran & 5.8 & 7.5 & 23.3 & 35.0 & 64.2 \\
& flour & 2.8 & 5.7 & 13.4 & 28.5 & 32.1 \\
\hline \multirow{2}{*}{ Wheat } & whole grain & 6.7 & 12.2 & 15.6 & 23.4 & 31.0 \\
(Triticum durum) & bran & 7.4 & 14.1 & 19.9 & 32.0 & 50.2 \\
& flour & 5.2 & 11.1 & 13.2 & 19.8 & 27.8 \\
\hline \multirow{2}{*}{ Rye } & whole grain & 10.6 & 18.9 & 25.8 & 32.7 & 45.0 \\
(Secale cereale) & bran & 12.2 & 23.8 & 28.7 & 38.6 & 59.1 \\
& flour & 7.2 & 16.9 & 19.4 & 26.3 & 30.2 \\
\hline
\end{tabular}

among antioxidants as well. Different methods used for measuring antioxidant activity based on different mechanisms may lead to different observations.

DPPH radical scavenging activity of morphological fractions was decreased in the following order: buckwheat hull, barley hull, rye hull and wheat bran (Table 2). These findings were not quite in agreement with total phenolic compounds which not decreased in the same order.

The grain fractions of wheat (whole-grain, bran and flour) have different antioxidant capacities [6]. Wheat bran extracts contain several phenolic acids, including vanillic, $p$-coumaric and, largely, ferulic acid. These compounds, particularly ferulic acid, are not evenly distributed in the wheat; most are found in the bran [20]. Extract of wheat bran, having high concentration of phenolic acids, was shown to have stronger antioxidant activity than other fractions of wheat. The aleurone layer is therefore the fraction with the highest antioxidant activity, followed by the bran fraction and whole grain. Some of industrial processes have been developed to isolate the aleurone layer, and then to enrich cereal products with it [21].

The antioxidant capacity of barley and barley extracts has been particularly studied in the field of beer production, since most of the phenolics in beer are derived from barley malt. Unlike wheat and oat, there has been little research on the antioxidant potential of barley and its fractions. However, the total phenolic content of barley is significantly correlated with the antioxidant capacity, as measured by the DPPH and ABTS assays [22].

The antioxidant activity of rye extracts (whole-grain, bran and flour) is significantly correlated with the total content of monomeric and dimeric hydroxycinnamic acids, with rye bran having the greatest antioxidant capacity [9].

\subsubsection{FRAP method}

Ferric reducing antioxidant power (FRAP) of the examined cereals, as shown in Table 1, correlated with total phenolic content. The highest FRAP value, expressed in $\mathrm{nmol}$ of $\mathrm{Fe}^{2+} / \mathrm{mg}$ dry extract, was found in buckwheat (49.43 $\mathrm{nmol} \mathrm{Fe}^{2+} / \mathrm{mg}$ dry extract), followed by lower FRAP in barley and wheat (15.56 and $12.15 \mathrm{nmol} \mathrm{Fe}^{2+}$ / mg dry extract, respectively), and the lowest ferric reducing antioxidant ability was found to be in rye (8.94 $\mathrm{nmol} \mathrm{Fe}^{2+} / \mathrm{mg}$ dry extract). Difficulty in the interpretation at comparison of data is even more obvious with the FRAP method. In our work, the results were expressed in $\mathrm{nmol}$ of $\mathrm{Fe}^{2+} / \mathrm{mg}$ dry extract, however other authors reported their results in $\mathrm{nmol}$ or $\mathrm{mmol} \mathrm{Fe} \mathrm{Fe}^{2+}$ in $\mathrm{mg}$ or $\mathrm{g}$ of grains or flour [23]. Besides, extraction solvents and methods of sample preparation used in other studies were different, and both were shown to have influence on FRAP. It is interesting that rye, which had significant DPPH radical inhibitory activity, showed the lowest ferric-reducing power (Table 1). It appears that care should be taken when using free radicals as a basis for antioxidant activity tests because the measured antioxidant activity of a biological sample depends on the free radical or oxidant that is being used in assay.

Wheat bran has been reported to be able to inhibit lipid oxidation catalyzed by either iron or peroxyl radicals [20]. Most recently, Zhou, and Yu [13] reported that wheat grain, bran and fractions had different antioxidant activities and total phenolic contents (TPC). Their study also showed that ferulic acid was a major contributor to the antioxidant activity. In a phosphatidylcholine liposome system, the percentage of liposome oxidation is reduced by increasing the concentration of isolated phenolic acids from whole-grain cereals [20].

The higher phenolic contents in the phenolics rich fractions exhibited the stronger antioxidant capacity than the phenolics less rich fraction. Ferulic acid and 
rutin were the major antioxidant compounds of buckwheat and existed mostly in the outer layers of grain. As a result, the outer layers of buckwheat grains with higher amount of phenolic compounds along with higher amounts of protein, lipid, ash and dietary fiber are considered to be good materials for cereal-based food processing with significant health benefits $[12,25,26]$.

\subsubsection{Thiobarbituric acid test (TBA)}

As shown in Table 1, there is a lack of correlation between TPC and the ability of lipid peroxidation inhibition in cereals. The cereals with higher TPC values were not necessarily better inhibitors of lipid peroxidation. An explanation of this may be in the complex mechanism of lipid peroxidation inhibition, which includes not only uncompounded phenols, but also high-molecular polyphenols and other nonphenolic antioxidants. According to results, rye had the greatest capacity for inhibition of lipid peroxidation of all cereals examined $(57.6 \%)$, followed by wheat and barley $(55.2 \%$ and $50.8 \%$, respectively), while the weakest results in TBA tests were for buckwheat (45.6\%) (Table 1). Besides, wheat extracts, for instance, demonstrated a high ability to inhibit lipid peroxidation in liposomes, but showed the lowest ability to directly react with and quench DPPH radical (Table 1). As already mentioned, these data may suggest that it might be more critical to suppress the initiation of radical chain reaction than to terminate it by removing the radicals generated during propagation of radical chain reaction $[23,24]$.

\section{CONCLUSIONS}

This study indicates, as we shown in our previous studies $(2,27)$ that cereals, used widely for human consumption, exhibit significant free radical scavenging activities, ferric-reducing power, capacity for inhibition of lipid peroxidation and total phenolic contents. Several significant differences were found among the cereals regarding these characteristics, which warrant further study, especially in terms of their effects on human health. Milling and refining process of grains can influence the presence and distribution of phenolic compounds and the final antioxidant power of cereal products. Processing of cereals may thus have a significant effect on their antioxidant activity. The concentration of grain antioxidants will be drastically reduced during the refining process. As phenolic compounds are found to be concentrated in the outermost layers, the bran fractions obtained as milling by-products may be used as a natural source of antioxidants and as a value-added product in the preparation of functional food ingredients and/or for enrichment of certain products.

\section{Acknowledgment}

Financial support provided by Ministry of education, science and technological development Republic of Serbia (number of project TR 31035) is greatly appreciated.

\section{ANTIOKSIDATIVNA AKTIVNOST RAZLIČITIH MORFOLOŠKIH FRAKCIJA ZRNA NEKIH CEREALIJA}

\author{
Slavica S. Šiler-Marinković ${ }^{*}$, \\ Suzana I. Dimitrijević-Branković1, \\ Tijana M. Đorđević ${ }^{2}$ \\ 1 Tehnološko-metalurški fakultet, Univerzitet \\ u Beogradu,Karnegijeva 4, 11000 Beograd \\ 2 Institut za pesticide i zaštitu životne \\ sredine, 11080 Zemun, Banatska 31 b, \\ P.O.B. 163 \\ * Autor za korespondenciju: \\ Slavica S. Šiler-Marinković, Tehnološko- \\ metalurški fakultet, Beograd, Karnegijeva \\ 4, 11000 Beograd, \\ siler@tmf.bg.ac.rs \\ $+38164 / 1397243$
}

\section{Kratak sadržaj}

Cilj rada je bio da se ispita antiooksidativna aktivnost etanolnog ekstrakta zrna cerealija i njihovih morfoloških frakcija. Ispitivani se: pšenica (Triticum durum L.), ječam (Hordeum vulgare L.), raž (Secale cereale L.) i heljda (Fagopyrum esculentum). Određivan je sadržaj ukupnih fenola (TPC) metodom po Folin-Ciocalteu i antioksidativna aktivnost (AOA) po tri najčešće korišćene metode: DPPH (sposobnost neutralizacije 2,2-difenil-1-pikrilhidrazil radikala), FRAP (antioksidativna sposobnost redukcije Fe 111 jona) i TBA ( metoda sa tiobarbiturnom kiselinom). Antioksidativna aktivnost etanolnog ekstrakta celog zrna opada u sledećem nizu: heljda>ječam>pšenica>raž. Isti odnos je dobijen i za mekinje. Spoljni slojevi zrna imaju veći sadržaj polifenola, pa sledstveno tome i veću antioksidativnu aktivnost. Heljda sadrži najviše polifenola i ima najveću antioksidativnu aktivnost određenu DPPH i FRAP metodom, ali ima najmanju sposobnost inhibicije lipidne peroksidacije.

Ključne reči: antioksidativna aktivnost, ukupan sadržaj polifenola, ekstrakt zrna cerealija, morfološke frakcije 


\section{References}

1. Emmons CL, Peterson DM, Pau, GL. Antioxidant capacity of oat (Avena sativa L.) extracts. 2. In vitro antioxidant activity and contents of phenolic andtocol antioxidants,Journal of Agricultural and Food Chemistry 1999; 47:4894-4898.

2. Đordević T, Šiler Marinković S, Dimitrijević Branković S. Effect of fermentation on antioxidant properties of some cereals and pseudo cereals. Food Chemistry 2010; 119: 957-963.

3. Adom KK, Liu RH. Antioxidant activity of grains. Journal of Agricultural and Food Chemistry2002; 50: 6182-6187.

4. Miller HE, Rigelhof F, Marquart L, Prakash A, Kanter M. Whole-grain products and antioxidants. Cereal Foods World2000; 45: 59-63.

5. Yu LL, Perret J, Harris M, Wilson J, Haley S. Antioxidantproperties of bran extracts from "Akron" wheat grown at different loocations. Journal of Agricultural and Food Chemistry 2003; 51: 1566-1570.

6. Liyana-Pathirana CM, Shahidi F. The antioxidant potential of milling fractions from bread wheat and durum. Journal of Cereal Science 2007; 45: 238-247.

7. Liu Q, Yao H. Antioxidant activities of barley seeds extracts. Food Chemistry2007; 102: 732-737.

8. Madhujith T, Shahidi F. Optimization of the extraction of antioxidative constituents of six barley cultivars and their antioxidant properties. Journal of Agricultural and Food Chemistry 2006; 54: 8048-8057.

9. Andreasen MF, Landbo AK, Christensen LP, Hansen A, Meyer AS. Antioxidant effects of phenolic rye (Secale cereale $L$.) extracts, monomeric hydroxycinnamates, and ferulic acid dehydrodimers on human low-density lipoproteins. Journal of Agricultural and Food Chemistry 2001; 49: 4090-4096.

10. Holasova M, Fiedlerova V, Smrcinova HM, Orsak J, Lachman S, Vavreinova I. Buckwheat-the source of antioxidant activity in functional foods. Food Research International 2002; 35:207-211.

11. Watanabe M, Ohshita Y, Tsushida T. Antioxidant compounds from buckwheat (Fagopyrum esculentum Moench) hulls. Journal of Agricultural and Food Chemistry1997; 45(4): 1039-1044.

12. Hung PV, Morita N. Distribution of phenolic compounds in the graded flours milled from whole buckwheat grains and their antioxidant capacities. Food Chemistry2008;109:325-331.

13. Zhou K, Yu L. Antioxidant Properties of Bran Extracts from Trego Wheat Grown at Different Locations.Journal of Agricultural and Food Chemistry2004; 52:1112-1117.

14. Zielinski $H$, Kozlowska $H$. Antioxidant activity and total phenolics in selected cereal grains and their different morphological fractions.Journal of Agricultural and Food Chemistry2000; 48(6):2008-2016.

15. Singleton V L, Rossi J A. Colorimetry of total phenolics with phosphomolybdic-phosphotungstic acid reagent. American Journal of Enology and Viticulture1956; 16: 144-158.

16. Cuendet M, Hostettmann K, Potterat O. Iridoid glucosides with free radical scavenging properties from Fagraea blumei. Helvetica Chimica Acta 1997; 80:1144-1152:

17. Szőllősi R, Szőllősi Varga I. Total antioxidant power in some species of Labiate (Adaptation of FRAP method). Acta Biologica Szegediensis 2002;46(3-4):125-127.

18. Gallardo C, Jimenez L, Garcia-Conesa MT. Hydroxycinnamic acid composition and in vitro antioxidant activity of selected grain fractions. Food Chemistry 2006; 99 : 455-463.

19. Maillard MN, Soum MH, Boivin P, Berset C. Antioxidant activity of barley and malt: Relationship with phenolic content. Lebensmittel-Wissenschaft \& Technologie 1996;29: 238-244.

20. Sun T, Ho CT. Antioxidant activities of buckwheat extracts. Food Chemistry 2005; 90:743-749.

21. Hemery Y, Rouau X, Lullien-Pellerin V, Barron C, Abecassis J. Dry processes to develop wheat fractions and products with enhanced nutritional quality. Journal of Cereal Science 2007; 46: 327-347.

22. Zhao HF, Dong JJ, Lu J, Chen J, Li Y, Shan LJ. Lin Y, Fan W, Gu GX. Effects of extraction solvent mixtures on antioxidant activity evaluation and their extraction capacity and selectivity for free phenolic compounds in barley (Hordeum vulgare L.). Journal of Agricultural and Food Chemistry 2006; 54: 7277-7286.

23. Xand B J, Chang S K C. A comparative study on phenolic profiles and Antioxidant activity of legumes as affected by extraction solvents. Journal of Food Science 2007; 72(2): 159-166.

24. Yu L, Haley S,Perret J, Hardis M, Wilson J, Qian M. Free Radical Scavenging Properties of Wheat Extracts. Journal of Agricultural and Food Chemistry 2002;50 (6):16191624.

25. Sedej I, Sakač M, Mandić A, Mišan A, Tumbas V, Čanadanović-Brunet J. Buckwheat (Fagopyrum esculentum Moench) grain and fractions: antioxidant compounds and activities. Journal of Food Science 2012; 77(9).

26. Kreft $S$, Janeš $D$, Kreft I. The content of fagopyrin and polyphenols in common and tartary buckwheat sprouts. Acta pharmaceutica 2013; 63(4): 553-560.

27. Đorđević T, Šiler-Marinković S., Dimitrijević- Branković S. Antioxidant activity and total phenolic content in some cereals and legumes. International Journal of Food Properties $2011 ; 14: 175-184$. 